\title{
ULOGA UPRAVNIH SUDOVA I SUDA EUROPSKE UNIJE U KREIRANJU PRAVNIH PROPISA I UPRAVNOSUDSKE PRAKSE
}

Izv. prof. dr. sc. Bosiljka Britvić Vetma*
UDK: 35.077 .3

https://doi.org/10.30925/zpfsr.40.1.15

Ur.: 21. prosinca 2018.

Pr.: 21. siječnja 2019.

Pregledni znanstveni rad

\section{Sažetak}

Uovom se radu prvenstveno razmatra uloga upravnih sudova u kreiranju pravnih propisa. Ističe se kako tumačenje zakonskih propisa, kao i njihova kvaliteta tumačenja definira i kvalitetu sudske prakse. Autor pritom naglašava kako to nije uvijek jednostavan zadatak. Navodi kako sudska praksa nije samo pravni, već i društveni fenomen. Tako svi društveni odnosi, koji zahtijevaju intervenciju zakonodavca, mogu pružiti sudcu priliku da razradi pravila sudske prakse. Iako sudska praksa nikada ne može zamijeniti pravno pravilo, ona je svakako logičan nastavak (produžetak) pravnih pravila, pa čak $i$ neophodni dodatak. Stoga je predmet interesa sudske prakse raznovrstan koliko je i interes pravnih pravila. Zato je doprinos upravnosudske prakse i njezina uloga jednako važna $i$ u životu pojedinca i u javnom životu. Budući da se pravilo odražava u presudi, presuda treba što preciznije prenijeti stvarni smisao zakona i misao sudca koji taj zakon primjenjuje, a ukupnost presuda treba moći činiti skladnu cjelinu. Obrazloženje daje legitimitet odluci i ujedno je objašnjava. Autor također u tekstu analizira do kojih granica seže primjena presuda Suda Europske unije, njegova interpretativna uloga, kao i koje obveze presude Suda Europske unije postavljaju pred državu članicu i njene građane. Ujedno ukazuje kako se prema njima trebaju odnositi nacionalni upravni sudci.

Ključne riječi: ciljno tumačenje; uvjeti oblikovanja upravnosudske prakse; značenje upravnosudske prakse; uloga europskih sudova $u$ kreiranju upravnosudske prakse.

* Dr. sc. Bosiljka Britvić Vetma, izvanredna profesorica, Pravni fakultet Sveučilišta u Splitu; bosiljka.britvic@pravst.hr. 


\section{1. $U V O D$}

Novija povijest potvrđuje da režim koji se bitno suprotstavlja slobodnom razvitku sudovanja, zadovoljavajući se formom i prividom, nije spojiv s vladavinom prava.

Kadabiznačenjezakona uvijek bilo razvidno, ne bibilo potrebe za interpretacijom, već bi upravni sudac samo trebao podvesti relevantne činjenice konkretnog slučaja pod određenu pravnu normu. Međutim, na samom prijelazu stoljeća, polazi se od toga da zakonodavac ne može predvidjeti sve moguće slučajeve izazvane dinamikom društvenog života, nego se mora ograničiti na generalno formuliranje pravnih normi, koje onda moraju biti interpretirane da bi se mogle primijeniti, a to znači da ih i stvaralački nadopunjuju njihovi adresati (sudci, stranke, javni službenici, odvjetnici, itd.).

Dugo se vremena postavljalo pitanje je li zadaća suca samo primijeniti zakon ili je sasvim prirodno da ga i „stvara“. Pobornicima klasične teorije, utemeljene na Roussovoj filozofiji nepogrešivosti prava te Montesquieuovom mišljenju, po kojem je sudac jedino „usta zakona“, suprotstavio se jedan moderan pravac koji je nastojao dokazati da, daleko od toga da bi bio samo „primjenjivač“ norme (zakona), sudac ima i kreativnu funkciju putem koje ,zaokružuje“ značenje pravne norme. Ova je teorija danas opće prihvaćena. Naime, više se ne osporava da sudac ima „kreativno normativnu moć", $\mathrm{tj}$. moć donošenja pravnih normi-zakonskog pravila s minimumom općenitosti, na način da se može primijeniti u određenom broju slučajeva ili barem više slučajeva. ${ }^{2}$ Ova „kreativno normativna moć“ je suštinski povezana sa sudbenom funkcijom, odnosno obvezom sudca da riješi spor.

Da bi sudovi primjenjivali zakonske propise na konkretne slučajeve (stvarajući sudsku praksu) u europskom kontinentalnom pravnom sustavu posežu za tumačenjem zakonskih propisa. Tumačenje zakonskih propisa, kao i njihova kvaliteta tumačenja definira i kvalitetu sudske prakse. Da to nije uvijek jednostavan zadatak potvrđuje i to da sudci tumačeći zakone moraju „pronaći” zakonski propis koji odgovara konkretnom slučaju koji se rješava. Kako je apstraktnost jedna od karakteristika zakona, a slučaj koji treba suditi konkretan, sličnosti i razlike koje se isprepliću između slučajeva posredno čine sudca provoditeljem i kreatorom prava. Sudac ne primjenjuje zakon samo formalno, niti mehaničkim čitanjem zakona pronalazi pravnu osnovu, već tumačenjem pronalazi pravnu volju zakonodavca (duh zakona), dakle stvaralački se odnosi prema konkretnom slučaju. Uvažavanjem presuđenih slučajeva, kojom se uvelike postiže izvjesnost sudske prakse, uvažava se i pravni stvaralački karakter sudca. ${ }^{3}$

Jasno je stoga koliko upravni sudci imaju upravo nezamjenjivu ulogu $\mathrm{u}$ uspostavljanju i održavanju teško ostvarive ravnoteže između općeg interesa i slobode pojedinca, između interesa države i prava pojedinca. Novija povijest pokazuje da je sudska praksa bila ta koja je osigurala podređivanje uprave pravu. Sudska praksa

2 Waline, M., Le pouvoir normatif de la jurisprudence, La technique et les principes du droit public, Etudes en l'honneur de G. Scelle, Pariz, L.G.D.J., 1950, t. 2, 913, str. 613-632. 
definirala je osnovna načela prava koja moraju obvezivati i izvršnu vlast i zakonodavnu vlast. Sudska je praksa time pružila svoj prilog načelu podjele vlasti. Naime, tek sudska praksa omogućuje pravnoj državi da bude i pravedna država. ${ }^{4}$

Proučavanje upravnosudske prakse i njezine važnosti u društvu i državi omogućuje provjeru nekoliko elemenata (čimbenika): uvjete oblikovanja upravnosudske prakse, u kontekstu upravnih sudaca s jedne strane i njihove sudske djelatnosti s druge; kao i ulogu sudske prakse (istražujući pritom njen stvarni domet $\mathrm{i}$ njene nužne ograničenosti).

Upravne sudce obvezuju pravne norme koje treba primijeniti. Ali upravne sudce obvezuje i sve što ih nadahnjuje u traženju pravednosti; a upravo to je sudska praksa. Kao jedan od ključnih problema kreiranja sudske prakse ističe se personalni kapacitet. Stoga se u svim liberalnim sustavima pitanje statusa sudaca, odnosno njihove nezavisnosti smatra iznimno važnim. Glavna „teškoća” za sudce je njihov odnos s druge dvije vlasti, zakonodavnom i izvršnom. ${ }^{5}$ Druga poteškoća koja zaokuplja danas duhove, tiče se duljine trajanja sudačke funkcije: doživotno ili na određeno vrijeme. ${ }^{6}$ Zbog toga je shvatljivo da kada se govori o nezavisnosti sudstva, općenito misli na nezavisnost u odnosu na političku vlast. Ali, iako je to najizravniji pojavni oblik problema, on nije i jedini, jer nezavisnost sudca mora postojati i prema njegovu društvenom okruženju te prema vladajućoj ideologiji.

Za nastajanje kvalitetne upravnosudske prakse potrebno je da su sudske odluke jasno obrazložene. Ta potreba podrazumijeva temeljiti trud sudca glede slova zakona, duha zakona, kao i pravnih načela, uz razumnost i zdravu razboritost.

Može se utvrditi da je sudska praksa proizvod sudske hijerahije. U tom smislu i jest uloga Vrhovnog suda Republike Hrvatske da osigura dvostruku funkciju. Najprije funkciju nadzora nad jedinstvom i koherentnošću pravnoga pravila koje primjenjuju sudovi, $\mathrm{u}$ interesu prvenstva zakona, $\mathrm{u}$ ime jednakosti svih pred zakonom, kao i pravne sigurnosti koju treba jamčiti građanima. Zatim i funkciju razjašnjavanja i modernizacije prava, u svrhu njegova razvitka i prilagođavanja životu i promjenama u društvu.

Naravno, upravni sudci svojim odlukama presuđuju pojedinačne slučajeve. Ali, ako se o situacijama, koje se pojavljuju pred sudcem, odlučuje na isti način, pojavljuje se određena pravilnost, a to je upravo vlastitost sudske prakse. Ona se pojavljuje kao ponavljanje odluka kojima daje snagu sudske vlasti. Naime, sudska praksa može postojati ako sudac interpretira zakon istodobno i jasno i trajno.

4 Primjeri zemlje kao što je Francuska, gdje se odlučujući koraci prema stvarnoj pravnoj državi učinjeni prije dvadesetak godina, pokazuju da je sudska praksa upravo bila ta koja je osigurala podređivanje uprave pravu. Sudska praksa Državnog savjeta i Ustavnog vijeća definirala je osnovna načela prava, koja moraju obvezati izvršnu i zakonodavnu vlast.

5 I zbog toga se zacijelo u Europi općenito mnogo više zanima i strahuje za kompetentnost upravnih sudaca.

6 U slučajevima doživotne funkcije, napredovanje u službi dodatna je teškoća, jer organiziranje tog napredovanja pretpostavlja: mogućnost prijelaza s jedne funkcije na drugu i evoluciju od nižih na više funkcije. 


\section{ZNAČENJE I STVARNI DOMET UPRAVNOSUDSKE PRAKSE}

Jedno od pitanja koje se nameće jest dokle može dosezati sudska praksa u ime izricanje pravične presude i dokle ta obveznost može dovesti upravnog sudca.

Po suvremenom europskom kontinentalnom pravu, sudska praksa pripada redu kodificiranoga prava zasnovanog na zakonu. Takvo dakle stanje, prema kojem su pravna pravila u cijelosti izrečena putem različitih pravnih tekstova, naizgled bi moglo isključiti potrebu postojanja sudske prakse. U tom slučaju upravni sudac ne bi trebao pokazivati nikakve inicijative i ne bi smio zauzimati i izricati određeni stav. On bi se morao ograničiti isključivo na doslovnu i dosljednu primjenu pravnih pravila na pojedine slučajeve. Svaki drukčiji stav upravnog sudca povrijedio bi slobodu građana i proturječio bi demokraciji. Zbog neodrživosti ovakvog, isključivo teorijskog modela, sudska praksa s vremenom postaje „pravedna primjena zakona”. Ona je ta koja potvrđuje pravno pravilo i koja ga „oživotvoruje”, jer upravni sudac taj koji ne određuje (izriče) samo što je zakonito, a što nije, nego i što je istinito i pravedno. Pravednost je zbog toga puno više negoli obično administriranje, pravednost je i vrlina, koja od upravnog sudca zahtijeva određenu etiku koja počiva na trajnom, osobnom nastojanju. Upravo na taj način sudci pridonose koherentnosti pravne države.

Sudska praksa nije samo pravni, već i društveni fenomen, utoliko što je ona način rješavanja sukoba u društvu. Tako svi društveni odnosi, koji zahtijevaju intervenciju zakonodavca, mogu pružiti sudcu priliku da razradi pravila sudske prakse. Iako sudska praksa nikada ne može zamijeniti pravno pravilo, sudska praksa je svakako logičan nastavak (produžetak) pravnih pravila, pa čak i neophodni dodatak. Stoga je predmet interesa sudske prakse raznovrstan koliko je i interes pravnih pravila, a njezin doprinos i uloga jednako su važni i u životu pojedinca i u javnom životu. ${ }^{7}$

Poslanje sudca, kako god ono bilo osjetljivo, neophodno je jer bi ljudi u naše doba teško prihvatili da se na njihove probleme primjenjuje samo formalistički postojeće pravno pravilo, kao kakav slijepi zakon. Sudci su stoga oči, uši i usta zakona. Nikad savršen, zakon je u najbolju ruku - najbolji u određenom trenutku, ali samo u tom trenutku. Na sudcu je da izriče što je pravo, uostalom odakle i ona latinska riječ iurisdictio.

U okvirima kodificiranog prava, kao i u sustavima pisanog prava, sudska praksa ima i vrši više funkcija. 1. Ona ponajprije primjenjuje, tzv. „opći zakon”, koji je $a$ priori teoretski i apstraktan. Ta primjena dovodi sudca do toga da mora precizirati domet pravnog pravila u odnosu na različite životne situacije, i to tako da primjenjuje propis u praksi. Tom prigodom upravni sudac i sudska praksa omeđuju područje primjene pravnih tekstova $i$, ako je potrebno, ustanovljuju smisao pojedinih pojmova koje pravni tekstovi nisu definirali. 2. Upravnosudska praksa isto tako ispunjava pravne praznine koje mogu postojati u pravnom pravilu, a ona to čini u općem duhu i pravnih pravila koji su na snazi i razboritosti, pravednosti kao i vrijednosti koje su u pitanju. 3. Upravnosudska praksa nalazi rješenja za ono što je ostalo nejasno, ona otklanja proturječnosti koje su izmakle zakonodavcu i koje sprječavaju pravilnu

7 Glede toga se ne smije smetnuti s uma da sloboda uopće postoji samo kroz niz posebnih sloboda. 
primjenu pravnih tekstova. 4. Upravnosudska praksa odgovara na nove situacije, koje nastoji svesti na postojeće zakone, prilagođavajući zakon evoluciji društva i osuvremenjavajući rješenja, koja izvodi iz zastarjelih pravnih tekstova. 5. I na koncu, upravnosudska praksa oblikuje smjernična načela, koja ujedinjuju raznorodne tekstove, dajući im smisao i jedinstvo na osnovi cjeline pozitivnog prava.

Za značenje i stvarni domet upravnosudske prakse, ali i općenito sudske prakse, posebno je važno stajalište Ustavnog suda Republike Hrvatske iskazano u jednoj njegovoj odluci iz 2011. godine. ${ }^{8}$ „Pozitivni smisao zahtjeva za određenosti i preciznošću pravne norme..... nije ispunjen ako građani, kao savjesne i razumne osobe, nagađaju o njezinu smislu i sadržaju, a njezini se primjenjivači često razilaze u njezinu tumačenju i primjeni u konkretnim slučajevima. Prijeporna tumačenja neke pravne norme, koja rezultiraju neujednačenom praksom upravnih i sudskih tijela, predstavljaju sigurnu naznaku pogrešaka i nedostataka u njezinoj određenosti. Negativni smisao zahtjeva za određenošću i preciznošću pravne norme upućene tijelu državne vlasti znači da njezin izričaj mora vezati to tijelo tako da mu ne dopušta postupanje izvan svrhe određene njezinim sadržajem. To je važno i za postupanje tijela državne i javne uprave i za postupanje tijela sudbene vlasti. Prva smiju postupati samo na temelju dovoljno jasnih zakonskih mjerila koja ih pravno vezuju ili im pak dopuštaju određeni stupanj slobodne prosudbe (najčešće u obliku diskrecijske ocjene). U suprotnom bi ono ugrozilo slobodu građana od samovolje i zlouporabe državne vlasti, posebice u slučajevima mjera i radnji koje se poduzimaju prema njima bez njihova prethodnog znanja." U istom kontekstu važno je istaknuti i odluku Ustavnog suda Republike Hrvatske iz 2000. i 2008. godine: ,Zakonodavac može na različite načine izbjeći neodređenost i nepreciznost pravne norme, uključujući i to da posebnim zakonskim definicijama odredi sadržaj pojedinim zakonskim pojmovima. No, pri tome je uvijek potrebno da činjenice-uvjeti u hipotezi zakonske norme sadrže elemente predvidljivosti ponašanja pravnih subjekata sukladne njezinom ustavnopravno prihvatljivom cilju (arg. iz zaključka njemačkog Saveznog ustavnog suda 1 BvF 3/92 od 3. ožujka 2004., § 113.). Konačno, moguće je i da se ustaljenom praksom sudbenih tijela u tolikoj mjeri otklone nejasnoće u tumačenju i primjeni neke norme da se može uzeti da njezin izričaj odgovara zahtjevima načela zakonitosti. Kojom će se metodom zakonodavac poslužiti Ustavni sud ne određuje. ${ }^{\text {(9) }}$ Potrebno je naglasiti da kako i upravni spor u Republici Hrvatskoj još uvijek ima mnoštvo nedorečenosti i praznina koje u praksi otežavaju djelovanje upravnih sudova. U tim okolnostima upravni sudovi u stvarnosti imaju veoma važnu ulogu. Isto tako je potrebno ukazati na značaj upravnosudske prakse koji se ogleda ponajprije u njezinoj gipkosti i boljoj prilagodljivosti konkretnim upravnosudskim situacijama. Reforma upravnog sudovanja nije svrha sama sebi, ona mora pružiti konkretne rezultate i omogućiti svakoj stranci ostvarenje prava na pravedno suđenje u razumnom roku. U tom kontekstu, ujednačena i kvalitetna sudska praksa bitan je čimbenik unaprjeđenja

8 Odluka i Rješenje Ustavnog suda Republike Hrvatske broj: U-I-722/2009 od 6. travnja 2011.

9 Ustavni sud u odluci broj: U-I-1085/2000 i dr. od 30. travnja 2008. kojom nije prihvatio neustavnost članka 337. Kaznenog zakona (NN, broj 110/97., 27/98., 129/00., 51/01., 111/03., 190/03., 105/04., 84/05. i 71/06.) zbog navodne povrede načela zakonitosti 
upravnosudske zaštite. ${ }^{10}$ Tako, primjerice, analizirajući Zakon o upravnim sporovima, može se zaključiti da je spor pune jurisdikcije zasnovan na općoj klauzuli, što je i bila intencija zakonodavca, ali je uvjetovana i ,prirodom stvari". ${ }^{11}$ Priroda stvari je odabir upravnosudske prakse i s obzirom na to da Zakon o upravnim sporovima koristi izraz priroda stvari, upravni sudovi nemaju apsolutnu obvezu riješiti upravnu stvar u sporu pune jurisdikcije. Upravni sud sam procjenjuje je li priroda stvari takva da on može riješiti upravnu stvar.

Stoga danas nitko ozbiljan ne stavlja u pitanje neophodnost sudske prakse. ${ }^{12}$

Nužno je naglasiti kako se argument u procesnopravnoj teoriji nikako ne svodi samo na sredstvo interpretacije pravne norme. Ništa manje nisu važni činjenični sudovi te zaključivanje i argumentacija pri utvrđivanju činjenica. I nad činjenicama se, da bismo došli do onih koje tvore činjenično stanje, obavlja kvalifikacija koju je nekad zaista teško odvojiti od interpretacije. I činjenični problemi mogu utjecati na karakteriziranje nekog slučaja „lakim” ili „teškim”. Dakle, sudovi kroz sudsku praksu stvaraju nova rješenja. ${ }^{13}$

\section{UVJETI OBLIKOVANJA (NASTANKA) SUDSKE PRAKSE - ZNAČENJE OBRAZLOŽENJA}

Pojedinačno prihvaćanje ${ }^{14}$ koje se objektivno vezuje za sudsku odluku postiže se putem mehanizma obrazloženja presude. Obveza davanja obrazloženja djeluje prirodno utoliko što je neosporan element kvalitete sudstva. ${ }^{15}$ Ona je „obrana od arbitrarnog djelovanja kojom se prisiljava sudca da osvijesti svoje mišljenje, svoj domašaj (...) i da (među ostalim) stranci iznese (pruži) obrazloženje svoje odluke“. ${ }^{16}$ Obrazloženje u konačnici mora jasno predočiti logiku kojom se koristio sudac i u tom smislu je ono obvezatno. Iako je obrazloženje temeljno načelo, prepoznato

10 O ovom vidi: Aviani, D., Đerđa, D., Uniformno tumačenje i primjena prava te jedinstvenost sudske prakse u upravnom sudovanju, Split, ZPFS, vol. 49, 2/2012, str. 369-394.

11 Priroda stvari je izraz koji doktrina koristi za opis stanja upravnog spora kojeg odlikuje jasna razlika između spora pune jurisdikcije i spora o zakonitosti, diobu vlasti između uprave i sudca, zabrana da sudac u postupku ocjene zakonitosti ide dalje od poništenja. Priroda stvari obično iskazuje evidentnost, odnosno stvarnost o kojoj treba voditi računa, ona je način opisivanja situacije koju sudac stvara kroz odabire utemeljene na upravnosudskoj praksi.

12 Danas je sudska praksa kao pravna i društvena nužnost općenito prihvaćena.

13 Vidi o tome Harašić, Ž., Autoritet i sud, Split, ZPFS, vol. 52, 2/2015, str. 407-429.

14 Uvjeriti znači nekoga navesti da povjeruje, shvati i zatim usvoji. Uvjeravanje je sila koja zna koristiti jezik kao stvarni alat za uvjeravanje, što omogućuje manje-više potpuno prihvaćanje nekog načina razmišljanja, logike, te u apsolutnom smislu rješenja. Ako to primijenimo na sudsku odluku, snaga uvjeravanja znači da želimo postići da je prihvati onaj kome je upućena. Ali s obzirom na to da prihvaćanje stvara subjektivni pristanak, gotovo „afektivni“ odnos, kako možemo prihvatiti neku sudsku odluku koja nam ne ide u prilog?

15 Budući da je obrazloženje srž svake presude, služiti se presudom bez iznošenja obrazloženja isto je kao da se netko služi tijelom bez duše, Ferrière, Dictionnaire de droit et de pratique, Pariz, 1779, citirao Jeuland, E., La motivation, u Dictionnaire de la Justice, Pariz, Loïc Cadiet, PUF, 2004, str. 912.

16 Guinchard, S., La théorie de l'apparence en droit administratif: vertus et risques de l'importation d'une tradition de Common law, Pariz, RD publ., 2005, str. 773. 
i prihvaćeno u svim pravosudnim sustavima, činjenica je da ga različite europske države različito. To može biti ustavna ${ }^{17}$ ili jednostavno zakonska ${ }^{18}$ obveza i u nekim se zemljama ograničava isključivo na prijepis silogističke logike, ukoliko ne prenosi imperativ razumijevanja usmjeren prema strankama (Austrija, Španjolska, Estonija, Madžarska, Irska, Nizozemska, Slovenija i Švedska).

Obveza davanja obrazloženja ne spominje se izričito u formulaciji Europske konvencije o ljudskim pravima ${ }^{19}$ i bilo je potrebno tumačenje sudaca u Strasbourgu kako bi ona postala sastavni dio prava na pravično suđenje. ${ }^{20}$ Sudci Suda u Strasbourgu dovode u vezu spomenutu obvezu, bilo s pravom na saslušanje predmeta pred sudom, ${ }^{21}$ bilo sa zahtjevom za nepristranošću suda. ${ }^{22}$ Europski sud za ljudska prava onda ocjenjuje in concreto poštovanje toga zahtjeva za obrazloženjem sudskih odluka u svjetlu specifičnih okolnosti karakterističnih za svaki predmet.

Obrazloženje omogućuje sudcu da „utvrdi, definira i opravda premise kako bi došao do konačne odluke ili zaključka." ${ }^{23}$ Obrazloženje je u tom slučaju sastavni dio sudske logike, premisa koja omogućuje da se dođe do zaključka, način izražavanja čija je namjera opisati itinerer kojim idu sudci, obvezujući ih da se ,izraze na način koji pokazuje da postupaju u skladu s pravilima ispravne logike ". ${ }^{24}$

Neke europske države obrazloženje doživljavaju kao spoj triju elemenata (činjenica, pravnih propisa i na kraju primjene prvih na druge u svrhu sastavljanja izreke); druge države stavljaju naglasak na razumijevanje stranaka kojemu obrazloženje treba pridonijeti. S jedne strane su obrazloženja koncizna, budući da ih se percipira isključivo kao instrument u službi sudca i težnja za brzinom, što dovodi do određenog formalizma u sastavljanju. ${ }^{25} \mathrm{~S}$ druge strane, obrazloženja su dugačka,

17 Italija (čl. 111., stavak 1.: „Sve sudske mjere moraju biti obrazložene“), Nizozemska (čl. 121.: „Izuzetak su slučajevi predviđeni zakonom, rasprave se održavaju u javnosti i presude su obrazložene, Belgija (čl. 149.: „Svaka presuda ima obrazloženje“), Grčka (članak 93., stavak 3.: „Svaka sudska odluka mora biti obrazložena na poseban i cjelovit način“).

18 Za pregled poredbenog prava, vidi Spencer, R. John, Quelques observations préliminaires, in Juges et jugements: l'Europe plurielle, l'élaboration de la décision de justice en droit comparé, Pariz, Société de législation comparée, 1998, str. 73.

19 Međutim, na temelju formulacije prvih redaka članka 6., stavka 1. spomenute Konvencije (,svatko ima pravo da...se ispita njegov slučaj...") lako je zaključiti kako ta obveza mora biti sastavni dio pojma pravičnog postupka u smislu da je nezamislivo da sudac ne obrazloži odluke koje donese upravo zbog opasnosti da ne ispita „slučaj“ na koji ima obvezu odgovoriti. Vidi o tome Boré, L., La motivation des décisions de justice et la Convention européenne des droits de l'homme, Pariz, JCP, 2002. I. 122: „Kada bi se sudu dopustilo da ne odgovori na dokaze koje iznese tužitelj, pravo stranke u postupku pred sudom bilo bi tek prazna školjka, isključivo fiktivno jamstvo"; vidi isto tako Europski sud za ljudska prava, 21. ožujka 2000., Pariz, Dulaurans, RTD civ. 2000, str. 439, bilješka J.-P. Marguénaud.

20 Europski sud za ljudska prava, 23. studenog 1992., Hadjianastassiou, Serija A, br. 252; Europski sud za ljudska prava, 19. travnja 1994., Van de Hurk, Serija A, br. 288; L. Boré, op. cit., str. 121.

21 Europski sud za ljudska prava, 16. prosinca 1992., Hadjianastassiou, Serija A, br. 252.

22 Europski sud za ljudska prava, 28. listopada 1987., H. c/ Belgique, Serija A, br. 127 B.

23 Ghirardi, A. Olsen, Le raisonnement judiciaire, Pariz, Ed. Bière, Bibliothèque de philosophie comparée, 2000, str. 39.

24 Ibid., str. 42.

25 Softver Ariane u Francuskoj. 
precizna i omogućuju stranci da dobro shvati smisao odluke. ${ }^{26}$

Obrazloženje predstavlja „očitost“ presude jer je plod inteligentnog razmišljanja koje omogućuje konkretnu primjenu teorijskog načela. Sâmo iščitavanje razmišljanja tog tipa trebalo bi gotovo automatski dovesti do prihvaćanja. ${ }^{27} \mathrm{U}$ konačnici obrazloženje sudskih odluka treba sagledavati ne tek kao instrument koji služi da se arbitrarnosti sudca suprotstavi logika utemeljena u pravu, nego i kao instrument u službi stranaka i da se time sagledaju pedagoški ciljevi.

U obrazloženju sudske odluke treba paziti na poštovanje dvaju kriterija: biti pravna podloga za izreku i biti sredstvo za razumijevanje koje koristi onome kome je namijenjeno. Ova dva zahtjeva u svojoj biti sastavni su dio zadaće suda. Obrazloženje daje legitimitet odluci i ujedno je objašnjava. Drugim riječima, opseg obveze objašnjenja sagledava se isključivo iz perspektive legitimnosti: odluka je obrazložena, utemeljena u pravu i prema tomu nužno shvaćena i prihvaćena. ${ }^{28,29}$

Obrazloženje odluka upravnih sudova priznaje i Zakon o upravnim sporovima koji propisuje da presuda mora sadržavati i obrazloženje, te da u obrazloženju sud izlaže zahtjeve stranke, činjenice koje su iznijele i dokaze koje su predložile, koje je činjenice sud utvrđivao, zašto i kada ih je utvrdio, a ako ih je utvrdio dokazivanjem, koje je dokaze izvodio i kako ih je ocijenio. ${ }^{30}$ Sud će posebno navesti koje je odredbe materijalnog prava primijenio odlučujući u sporu i izjasniti se o prijedlozima i prigovorima stranaka o kojima nije iznio razloge tijekom spora. Đerđa i Šikić ističu kako bi se tako detaljnim propisivanjem sadržaja obrazloženja presude u Zakonu o upravnim sporovima trebala spriječiti pojava sudskih obrazloženja koja faktično ništa ne obrazlažu, a pogotovo ne obrazlažu primjenu materijalnog prava. ${ }^{31}$

Mnogostruku važnost obrazloženja u nizu svojih presuda istaknuli su Ustavni

26 Uglavnom je riječ o tradiciji sustava common law.

27 Pedagogija je nužno rezultat procesa logike suda, ali ako se držimo te konstatacije, pedagogija kojoj težimo nužno je okrenuta sama sebi dok se ne možemo zadovoljiti odlukom koja se smatra pravednom, budući da ljudski duh želi znati zašto je takva i kako je donesena.

28 Jednostavna logika koja ide samo za primjenom pravnog načela nije zadovoljavajuća i treba joj nadodati logiku koja se nadahnjuje normama uvjeravanja. Jasno je da upravni sudac mora objasniti, argumentirati, a da se ne zadrži samo na logici racionalnosti, kako bi njegova odluka bila učinkovito prihvaćena od stranaka. Međutim, to podrazumijeva da treba udahnuti dozu retorike u sustav koji je načelno odbacuje. Deduktivni duh čini po svojoj prirodi argumentaciju štedljivom budući da je silogistička logika sama sebi dostatna i to je u teoriji čini izravno prihvatljivom strankama. Osim toga, toj novoj dimenziji koja se pripisuje zahtjevu obrazloženja suprotstavlja se jedan drugi potpuno antagonistički zahtjev: težnja za brzinom ili pravosudnom produktivnošću koju ponekad podupiru poticajne mjere. Pedagoški pritisak tu popušta pred pritiskom brojki, kvantitete. Dok prva dovodi do očiglednog produljenja postupka, druga zahtijeva obrnuti ekstrem.

29 Više o svemu vidi Britvić Vetma, B., Kvaliteta odluka upravnih sudova, Split, ZPFS, vol. 51, 2/2014, str. 393-414.

30 O važnosti obrazloženja odluke u upravnom postupku vidi u Đerđa, D., Učinak europskih pravnih pravila na pravno normiranje upravnog postupka u Hrvatskoj, Split, ZPFS, vol. 50, 2/2013, str. 415-417.

31 Đerđa, D., Šikić, M., Komentar Zakona o upravnim sporovima, Zagreb, Novi informator, 2012, str. 262. 
sud Republike Hrvatske i Visoki upravni sud Republike Hrvatske. ${ }^{32}$ Obrazloženje je važno i zbog uobličavanja buduće prakse nižih sudova. ${ }^{33}$

\section{INTERPRETATIVNA ULOGA SUDA EUROPSKE UNIJE}

U Republici Hrvatskoj kao jednoj od novijih država članica Europske unije, nužno se postavljaju određena pitanja vezana uz primjenu presuda Suda Europske unije. Kao, primjerice, do kojih granica seže primjena presuda Suda Europske unije? Koje obveze spomenute presude postavljaju pred državu članicu i njene građane? Kako se prema njima trebaju odnositi nacionalni upravni sudci?

U okviru Europske unije, Sud Europske unije zauzima posebno mjesto jer se, između ostalog, temelji na ugovorima čiji je učinak s obzirom na nacionalna prava posebno proširen. Odredbe tih ugovora, ne samo da imaju prednost pred nacionalnim pravom, već ih je nacionalni upravni sudac obvezatan izravno primjenjivati, te se na njih može pozvati svaka zainteresirana osoba. Svrha Suda Europske unije je osigurati pravilno tumačenje te pravilnu primjenu primarnog i sekundarnog zakonodavstva Europske unije. Sud Europske unije je istovremeno i institucija koja je zadužena, jednako kao i Vijeće, Komisija ili Parlament, da bdije nad ostvarivanjem zadaća Unije.

Na razini Europske unije, istovremeno postoji podudarnost između podvrgavanja vladavini prava i obveze uzimanja u obzir rješenja Suda Europske unije. Njegova je nadležnost obvezujuća i ostvaruje se i u odnosu na nacionalne upravne sudove i u odnosu na javnopravna tijela.

Prema tomu, Europska unije, sveobuhvatno koristi ovlasti koje potiču na rastuću integraciju tako što pojedincima daje pravo na koje se može izravno pozvati pred nacionalnim upravnim sudovima. Sud u Luxembourgu time svoje djelovanje temelji na konceptu ,suradnje“" $s$ nacionalnim pravnim sustavima.

Hrvatsko se pravo treba još uvijek prilagođavati, i danas, kada je Hrvatska punopravna članica Europske unije, europskom pravnom sustavu. Naime, novi izvori prava, pojavljuju se zajedno s rastućom globalizacijom i europeizacijom te neprestano nameću nova pravila i nove standarde. ${ }^{34}$

32 Vidi primjerice US-13302/2009-5 od 26. siječnja 2012.

Đerđa ističe: „Na obrazloženju rješenja inzistira i sudska praksa, navodeći kako se upravo pomoću obrazloženja utvrđuje je li se javnopravno tijelo rukovodilo načelom zakonitosti i postupalo tako da u vođenju upravnog postupka i u odlučivanju omogući stranci što lakše zaštititi svoja prava i pravne interese, te da se nenavođenjem razloga kojima se nadležno tijelo vodilo pri odbijanju zahtjeva stranke krši ustavno pravo jednakosti pred zakonom, jer je stranka u postupku koja ne zna te razloge u nejednakom položaju prema onima kojima su razlozi poznati pa zbog toga ne može valjano štititi svoja prava niti na učinkovit način ostvariti Ustavom zajamčena prava na pravnu zaštitu.“ Đerđa, D., Učinak europskih pravnih pravila na pravno normiranje upravnog postupka u Hrvatskoj, cit., str. 416-417.

33 Vidi Harašić, Ž., Autoritet i sud, cit., str. 407-429.

34 Brzina, obujam i složenost promjena, na posredan će način prisiliti sudce da prate praksu domaćih sudova, ali i praksu Europskog suda za zaštitu ljudskih prava i Suda Europske unije i da u njoj traže uporište za rješavanje konkretnih sporova. Zbog toga je proučavanje artikulacije između nacionalnog i europskoga pravnog poretka privilegirano područje dijaloga između nacionalnih i europskih sudaca već pola stoljeća. Kao što je naglašavao Bruno Genevois, istinski začetnik 
Ostvarivanje prava koja proizlaze iz pravne stečevine Europske unije, izjednačeno je s ostvarivanjem prava koja su zajamčena hrvatskim pravnim poretkom. Pravni akti i odluke koje je Republika Hrvatska prihvatila u institucijama Europske unije primjenjuju se u Republici Hrvatskoj u skladu s pravnom stečevinom Europske unije. Hrvatski sudovi štite subjektivna prava utemeljena na pravnoj stečevini Europske unije. Državna tijela, tijela jedinica lokalne i područne (regionalne) samouprave te pravne osobe s javnim ovlastima izravno primjenjuju pravo Europske unije (članak 141.c Ustava). U skladu s navedenim, potrebno se osvrnuti i na članak 141.d Ustava Republike Hrvatske koji u svojim odredbama ističe kako su državljani Republike Hrvatske građani Europske unije, i u skladu s tim uživaju sva prava koja im jamči pravna stečevina Europske unije te uživaju jednaka prava kao i svi građani Europske unije. $^{35}$

Iz navedenih članaka Ustava Republike Hrvatske proizlazi ustavna obveza primjene europskog prava $\mathrm{u}$ nacionalnom pravnom poretku uz poštovanje načela svojstvenih europskom pravnom poretku. Štoviše, Republika Hrvatska, otada ima ustavnu obvezu, a ne samo europsku, da „korigira“ svoju politiku prijenosa europskih direktiva. ${ }^{36}$ Ta kontrola sukladnosti ili kompatibilnosti zakona kojim se prenosi direktiva, sa samom direktivom, odraz je nove koncepcije mjesta koje zauzima europsko sekundarno pravo u nacionalnom pravnom sustavu.

U mjeri u kojoj je u ovom desetljeću Republika Hrvatska angažirana u provođenju jedne od najvećih pravnih reformi u svojoj povijesti, možemo reći da je riječ o pravoj upravnopravnoj revoluciji. ${ }^{37}$ Sva područja djelatnosti dotaknuta su europskim stečevinama, koje hrvatsko pravo treba ne samo apsorbirati već i primjenjivati u praksi. Navedeno pretpostavlja da osim nekih 120.000 do 200.000 stranica pravnih mjera Unije, treba usvojiti i dosadašnju (pedesetak) sudsku praksu Suda Europske unije koja je iznimno bogata i obvezujuća. Dovoljno je spomenuti njegove dvije odluke, od 23. veljače 2013. (predmet Stefano Melloni c/Ministerio fiscal ${ }^{38}$ i predmet Akerberg Fransonn ${ }^{39}$ ), koje pokazuju da odredbe Povelje o temeljnim pravima Europske unije,

koncepta „dijaloga sudaca“, odnosi između sudova Europske unije i nacionalnih sudova u znaku su dijaloga i suradnje. I upravo zbog toga Europska unija danas pronalazi svoju dosljednost. Prvenstvo europskog prava čini svaku nespojivu nacionalnu normu neprimjenjivom. Ono „znači da je nadležnim nacionalnim vlastima u potpunosti zabranjeno primijeniti nacionalnu odredbu koja je nespojiva s ugovorom te, ako je potrebno, da imaju obvezu poduzeti sve mjere kako bi olakšale potpuno ostvarivanje europskog prava." Sud Europske unije, 13. srpnja 1972., Commission c/ Italie, predmet 48-71.

35 Staničić, F., Britvić Vetma, B., Horvat, B., Komentar Zakona o upravnim sporovima, Zagreb, Narodne novine, 2017, str. 51.

36 Četiri su najvažnija elementa približavanja sudskih praksi hrvatskog i europskoga pravnog poretka su: prvenstvo i specifičnost europskog prava; izravni učinak europskih direktiva; tumačenje europskog prava i recepcija načela pravne sigurnosti u nacionalnom pravnom poretku. Oni su povezani s recipročnim uklapanjem nacionalnog i europskog pravnog poretka te s ovlastima nacionalnih sudaca u njihovoj zadaći tumačenja i primjene prava.

37 U sadašnjem trenutku, očekivanja Europske unije odnose se, između ostalog, na javnu upravu i upravno sudovanje.

38 Predmet C399/11.

39 Predmet C617/10. 
imaju prednost nad nacionalnim pravilima $\mathrm{u}$ stvarima koje $\mathrm{u}$ potpunosti uređuje pravo Unije. No, i u svim ostalim područjima, nacionalno pravo ne može dovesti u pitanje načela prednosti, jedinstva i učinkovitosti europskog prava. Stoga je danas potpuno jasno da europsko pravo uvelike utječe na nacionalna prava.

Pravo zajednice bilo je podložno interpretaciji već zbog svojih vlastitih karakteristika. Po svojoj prirodi, europske norme su djelomične i programatske te zahtijevaju interpretativnu nadopunu. One su podložne primjeni metoda konstruktivne interpretacije sistematskog i teleološkog karaktera. Tako uspostavljena pravna konstrukcija poziva u svim svojim dimenzijama, da se nadopune praznine, otklone nejasnoće, pojasne nedorečenosti za koje nikako nije isključeno da neke nisu i namjerne, dok su druge bile tehnički neizbježne, ali ni jedne ni druge ne bi mogle navesti sudca da odustane od svoje misije. Iz navedenih razloga, ugovori impliciraju priznavanje interpretativne funkcije Suda, kako bi se omogućio progresivni razvoj institucionalnih ciljeva Zajednice. ${ }^{40}$

Stoga ulaskom Republike Hrvatske u Europsku uniju postoji potreba za upravne sudce koji su u stanju razumjeti, poštovati i primjenjivati pravo Zajednice. Osim što je sasvim normalno od upravnih sudaca očekivati učinkovitost, njihova primarna misija je zaštita općeg interesa, zaštita subjektivnih prava stranke i poštovanje zakona. ${ }^{41}$

Poznato je da se Sud Europske unije ne može jednostavno definirati tradicionalnim institucijskim kanonima. Djelovanje Suda Europske unije sastoji u osiguravanju trajnosti i poštovanju sveukupnih europskih normi na kojima počiva i njegova institucionalna utemeljenost. Njegov je status kompleksan i ne može se reducirati na transpoziciju kategorija koje se obično koriste u definiranju poznatih pravosudnih instanci međunarodnog ili nacionalnog tipa.

Sud Europske unije putem regulatorne funkcije kada odgovara na prethodna pitanja, usko je povezan s nacionalnim pravom. Sud postaje i međunarodna jurisidikcija kada se bavi postupanjem država članica u odnosu na njihove obveze s obzirom na Zajednicu, osobito kada ih kažnjava za propuste ili kada presuđuje u sporovima među državama članicama.

Kroz niz, različitih, postupaka Sud, kao institucija Europske unije, pazi na poštovanje prava Europske unije u primjeni i interpretaciji ugovora. Na temelju članka 267. Ugovora o funkcioniranju Europske unije, on jedini daje autentičnu interpretaciju europskog prava. Ispunjavanje ove funkcije prirodno više podrazumijeva stvaranje, a ne samo iščitavanje prilagođeno konkretnom slučaju. Sud je prilagodio svoje interpretativno rezoniranje stupnju integracije Zajednice, a potom i Unije.

40 Suočeni s ovom neuvijenom potvrdom prvenstva europskog prava nad svim normama nacionalnog prava, pa bile one i na ustavnoj razini, nacionalni sudci moraju razmotriti rješenja iz vlastite sudske prakse. O tomu je pisao Jean-Marc Sauvé: „,.. Državni savjet je prvo bio „neposlušan učenik“, čak i „buntovan“, koji je pokazivao svoje nepovjerenje prema sudskoj praksi Suda Europske unije i prema europeizaciji javnog prava, a zatim se malo po malo pretvorio u suradnika, da bi na kraju postao proaktivna i konstruktivna instanca kakav je danas“.

41 Kao regulator društvenih odnosa, sudac osigurava prvenstvo prava i pravednosti, rješavajući sporove između pojedinaca, između njih i uprave, ograničavajući moguća odstupanja političke vlasti. 
U svjetlu ove interpretativne metode izgrađena je sudska praksa. ${ }^{42}$ Sud nastoji postići ravnotežu između razvoja nadležnosti i ovlasti koje se pripisuju Zajednici, a potom i Uniji, te poštovanju namjera koje su izričito izrazili autori ugovora. ${ }^{43}$ Sudac pazi da ne narušava njihovu volju. Sud Europske unije pridonosi obogaćivanju pisanog zakona njegovom konkretizacijom. Njegova se sudska praksa uključuje u tumačenu odredbu, jer daje njeno značenje i objektivni opseg, koji na taj način evoluira. ${ }^{44}$

\section{SUD EUROPSKE UNIJE I OPĆA PRAVNA NAČELA}

Baš kao i sudovi država članica, Sud Europske unije poziva se na opća načela prava i osigurava njihovo poštovanje. Sud je utvrdio ova načela radi jačanja sveukupne koherentnosti pravnog sustava Zajednice i naglašavanja koncepta Zajednice prava. Pritom razlikujemo načela koja proizlaze iz same prirode Zajednice, koja proizlaze iz gospodarskog sustava uspostavljenog ugovorom i ciljevima izgradnje zajednice. Ova se načela ostvaruju generalizacijom određenih odredbi Ugovora ili proizlaze iz sveukupnosti tekstova Zajednice. Neka od tih pojedinih načela su institucionalne naravi. $^{45}$

Druga skupina uključuje načela koja su svojstvena svakom organiziranom pravnom sustavu. Kreativna funkcija Suda jasno se pojavljuje kada objavljuje ta načela, jer najčešće sam sudac ne navodi njihove izvore. Sud ih implicitno crpi iz načela koja postoje u nacionalnim poredcima, ali nisu izravno povezana $\mathrm{s}$ njima, primjerice, u slučaju načela zakonitosti i općeg načela prava na žalbu, načela pravne sigurnosti, načela zaštite stečenih prava stranke, načela postupanja u dobroj vjeri, načela „,dobre uprave“ itd., koja imaju ključnu ulogu u upravno postupovnom pravu.

Također ovdje moramo spomenuti i načela koja su zajednička načela država članica. ${ }^{46}$ Naime, već od prvih presuda Suda Europske unije postavljeno je pitanje da li bi Sud mogao koristiti načela država članica u tumačenju odredbi Ugovora. Sud

42 Potaknut željom da europskom pravu osigura puni učinak, Sud Europske unije dopustio si je odlučivanje ultra petita kad to zahtijeva interes europskog prava. U presudi Roquette iz 1980. (Sud Europske unije, 15. listopada 1980., predmet 145/79.), Sud navodi kako su u okviru podjele funkcija između nacionalnih sudova i Suda u svrhu primjene članka 177. EEZ (234. EZ, 267. EUFU) nacionalni sudovi zaduženi odlučiti o relevantnosti postavljenih pitanja, no Sud si zadržava pravo da iz elemenata koje dostavlja nacionalni sud izvuče one elemente europskog prava koji, s obzirom na predmet spora, zahtijevaju tumačenje ili ocjenu valjanosti.

43 „Izvršna snaga europskog prava ne može varirati od jedne do druge države po volji nacionalnog zakonodavstva nastalog naknadno a da ne dovede u opasnost ostvarivanje ciljeva ugovora." Sud Europske unije, 15. srpnja 1964., Costa c/ Enel, predmet 6-64.

44 Više o svemu vidi: Britvić Vetma, B., Suradnja između nacionalnih upravnih sudova, Suda Europske unije i Europskog suda za zaštitu ljudskih prava, Rijeka, ZPFR, vol. 35, 1/2014, str., 219-244; Britvić Vetma, B., Ljubanović, B., Suradnja između nacionalnih upravnih sudova, Suda Europske unije i Europskog suda za zaštitu ljudskih prava u izvršavanju upravnosudskih odluka nakon Lisabonskog ugovora, Split, ZPFS, vol. 52, 2/2015, str. 431-447.

45 Gaudemet, Y., Droit administratif, Pariz, L.G.D.J., 2005, str. 34-40.

46 Đerđa, D., Načelo razmjernosti u donošenju upravnih odluka, Rijeka, ZPFR, vol. 37, 1/2016, str. 175-200. Šikić, M., Ofak, L., Nova načela upravnog postupka (s posebnim naglaskom na razmjernost, legitimna očekivanja i stečena prava), Rijeka, ZPFR, vol. 32, 1/2011, str. 127-153. 
je odgovorio na ovo pitanje primjenjujući načela nacionalnog prava država članica: Ovo je problem upravnog prava dobro poznat u sudskoj praksi i doktrini svih zemalja Zajednice, ali za rješenje kojeg ugovor ne sadrži pravila. Sud je, kako ne bi počinio uskraćivanje pravde, dakle, bio dužan razriješiti problem oslanjajući se na pravila definirana u zakonima, teoriji i sudskoj praksi zemalja članica. ${ }^{47} \mathrm{U}$ ovakvom pristupu, Sud ne provodi združivanje nacionalnih načela, već povlači zaključke u duhu njihovih nacionalnih prava, njihovih općih usmjerenja, zajedničkog nazivnika, koji mogu poslužiti kao osnove načela Zajednice. Iako su ti standardi izvedeni iz zakona država članica, kreativni voluntarizam Suda široko se manifestira.

Sud je utvrdio i jednu drugu kategoriju načela koja se tiču temeljnih prava. Ta se prava odnose na sva ljudska prava i javne slobode, koje su općenito zajamčene nacionalnim ustavnim pravima i međunarodnim instrumentima ljudskih prava, među kojima Europska konvenciju za zaštitu ljudskih prava i temeljnih sloboda ima vodeću ulogu. Među temeljnim pravima sadržanim u sudskoj praksi Suda Europske unije su i sva prava pojedinca na poštovanje privatnog i obiteljskog života, doma i dopisivanja te vjerske slobode. Osim toga, tu su i prava koja se odnose na gospodarski i društveni život, kao što je pravo na imovinu, pravo na slobodno ostvarivanje gospodarskih djelatnosti, zaštitu poslovne tajne, slobodu udruživanja ili slobode izražavanja. Većina je tih načela kodificirana u Povelji o temeljnim pravima Europske unije, koja je stupila na snagu s Lisabonskim ugovorom ${ }^{48}$ Iz svega navedenog proizlazi da se Sud ne ograničava samo na pravila i načela, već u stvarnosti ostvaruje kreativnu funkciju zakona budući da razrađuje modele novih odnosa među ljudima i državama koje čine Zajednicu. ${ }^{49}$ On je treća strana koja ima istinsku funkciju nadležnosti (jurisdictio), a ne puko zakonodavstvo (legisdictio). Čin je stvaranja očit, a opća načela čine najcjelovitiji oblik sudske kreativnosti. Čak i ako Sud ukaže na nešto što je već sadržano u postojećem pravu, presuda i sudska praksa stvaraju novi standard. Kada Sud Europske unije promiče neko opće načelo, kao što je pravna sigurnost, on ga izvodi iz određenih odredbi izvornog teksta, ali prije svega konačnom interpretacijom, kako bi se konsolidirao pravni poredak Zajednice; on ga stvara u trenutku kada ga formalizira u svojem sudskom postupku. Iako većina temeljnih načela i prava imaju ustavno ili državno ustavno podrijetlo, oni su više rezultat tumačenja Suda Europske unije i njihove prilagodbe pravnom poretku Zajednice. Tumačenja i prilagodbe koje čini Sud Europske unije proizlaze iz logike stvaranja, a ne pasivnog izvođenja zaključaka. On ispunjava svoju ulogu sudskoga tijela uključivanjem u proces formiranja zakona. Treba naglasiti da je njegova normativna sudska praksa, izraz zakonodavne povlastice te ima višu hijerarhijsku vrijednost od sekundarnog prava Zajednice.

47 Sud Europske unije, 12. srpnja 1957., Algera i ostali, predmet 7/56 i 3/57 do 7/57.

48 Mertens de Wilmars, J., La jurisprudence de la Cour de justice comme instrument de l'intégration communautaire, Bruxelles, C.D.E., 1976, n¹2., str. 135-148. Ibid., str. 148. 


\section{VAŽNOST I UTJECAJ PRAKSE SUDA EUROPSKE UNIJE}

Važno je istaknuti da su sudska praksa i opća načela izraz prerogativa javne ovlasti budući da su obvezujući za institucije u izradi sekundarnog zakonodavstva i u državama članicama. Ipak, njihova značaj i utjecaj nemaju istu osnovu. Treba posebno razlikovati važnost normativne sudske prakse, od općih načela prava Zajednice.

Pitanje normativnog tumačenja Suda Europske unije nije ograničeno samo na prethodno pitanje. Naime, tumačenje pravne norme nije rezervirano samo za ovu vrstu postupanja, već ono obuhvaća cjelokupnu nadležnost Suda. U slučaju tužbe za neispunjavanje obveze ili tužbe za poništenje, Sud Europske unije može također tumačiti odredbe Ugovora. Spomenuta tumačenja imaju isti autoritet kao na temelju članka 267. Ugovora o funkcioniranju Europske unije.

Pitanje dosega interpretativnih prosudbi Suda izazvalo je mnoge kontroverze. Pitanje je ima li tumačenje Suda učinak samo u postupku za kojeg je izdano ili vrijedi i za sve ostale slučajeve u kojima se ovo pitanje postavlja. Ovo pitanje je presudno: riječ je o tomu da se razjasni jesu li nacionalni upravni sudovi koji odlučuju u budućim sporovima, u kojima se pojavljuje isto pitanje tumačenja, slobodni ili ne, usvojiti drugo tumačenje, ako bi presuda imala samo „moralni autoritet“. U preliminarnim pitanjima očito je da upravni sudac koji je postavio pitanje mora uzeti u obzir odgovor koji je sam zatražio, ali što je s ostalim sudcima? $?^{50}$ Sud daje konsenzualni odgovor na to pitanje smještajući raspravu, ne u područje autoriteta res judicata, nego u područje autoriteta tumačene stvari, pozivajući nas da razlikujemo pojmove autoriteta kao i nepromjenjivost tumačene stvari. Takva sudska praksa temelji se na ideji da je sudsko tumačenje ugrađeno u tumačenu normu, koju ono specificira, razvija i obogaćuje.

\subsection{Načelo autoriteta tumačene stvari u interpretativnim presudama}

Doktrinalne kontroverze o pitanju autoriteta interpretativnih presuda su stare i usredotočene na pitanje jesu li presude imale apsolutni ili relativni autoritet o pitanju res judicata. Za zastupnike relativnog autoriteta, glavna je briga bila da se ne priguši zakon Unije i da ga se jednom zauvijek ne zaključa u nekom tumačenju. Takvo je bilo mišljenje generalnog odvjetnika Lagrangea, koji je smatrao da je potrebno mudro „pravilo“, ${ }^{1}$ koje će omogućiti sudsku evoluciju. S druge strane, za ostale, apsolutni autoritet res judicata činio se prikladan za očuvanje javnog reda zajednice. Teza o relativnom autoritetu res judicata imala je velike nedostatke. Naime, to bi moglo u kratkom roku dovesti do zagušenja Suda Europske unije, pogotovo što nije bila prilagođena ciljevima Ugovora, osobito onima sadržanim u članku 267. Ugovora o funkcioniranju Europske unije, koji ima za cilj očuvanje javne politike Zajednice i Zajednice prava putem jedinstvene $\mathrm{e}^{52} \mathrm{i}$ homogene interpretacije $\mathrm{e}^{53}$ osnovnih ugovornih

50 Sud Europske unije, 3. veljače 1977., Benedetti, predmet 52-76.

51 Sud Europske unije, 27. ožujka 1963., Da Costa en Schaake, spojeni predmeti 28, 29, 30/62, rec., str. 79-91.

52 Teitgen, P.-H., Cours de droit institutionnel communautaire. Structure et fonctionnement des Communautés européennes, Licence $4^{\mathrm{e}}$ année, Pariz, Les cours de droit, 1976-1977, str. 510.

53 Trabucchi, A., L'effet erga omnes des décisions préjudicielles, Pariz, R.T.D.E., 1974, str. 56. 
odredbi. Sud je morao formulirati apstraktni odgovor, koji ima potencijalno jedinstveno značenje, za sve eventualne nedoumice koje bi mogle nastati po istom pitanju. Kao odgovor na ove različite argumente, Sud je konstruktivno protumačio članak 267. Ugovora o funkcioniranju Europske unije, koji omogućava simultano uvažavanje ovih doktrinalnih pozicija, iako disonantnih. Položaj Suda je nijansiran.

On vraća natrag zastupnike apsolutnog autoriteta kao i one relativnog autoriteta res judicata, razlikujući obvezu koja se nameće nacionalnim upravnim sudovima od mogućnosti da se bilo koji nacionalni upravni sudac obrati Sudu s pitanjem tumačenja Ugovora, Sud potvrđuje da „ako Ugovor o funkcioniranju Europske unije obvezuje upravne sudove čije odluke ne podliježu sudskom nadzoru nacionalnog (domaćeg) prava, na traženje tumačenja pitanja koje se postavlja pred njima, autoritet (nadležnost) tumačenja potonjeg može, međutim, oduzeti tu obvezu svog uzroka i lišiti je sadržaja. Osobito kada je postavljeno pitanje materijalno istovjetno pitanju koje je već predmet prethodnog rješenja u sličnom slučaju. Međutim, ipak se dopušta nacionalnom sudu, ukoliko smatra da je to potrebno, da ponovno uputiti Sudu zahtjev za tumačenje". ${ }^{54}$

Položaj Suda je suptilan i zaslužuje nekoliko objašnjenja. Prema Sudu, prethodno pitanje ukida obvezu „viših“ sudova da ponovno upute predmet Sudu Europske unije, budući da moraju poznavati već tumačenu odredbu Zajednice. No, u takvoj situaciji oni, poput nižih sudova, moraju ili primjenjivati presudu ili se ponovno obratiti Sudu Europske unije. Ni na koji način ne mogu je primijeniti u smislu različitom od onoga koji je odredio Sud. Diskrecija koja se dodjeljuje Visokom upravnom sudu Republike Hrvatske temelji se na razlikama između „predmeta“ i „uzroka“ tužbe. Stoga, kada je Sud sazvan radi tumačenja, on zahtjev ne odbacuje a priori kao nedopušten samo zato što je o tom pitanju već odlučeno. Naprotiv, on ga prihvaća. Međutim, ako utvrdi da ne postoji materijalna razlika, niti pojava nekoga novog elementa, Sud će smatrati da je „uzrok” postupka nestao i vratit će se na prethodnu presudu, tvrdeći da nema mjesta za novo tumačenje, osim, naravno, ako smatra da ga je potrebno izmijeniti. Drugim riječima, prema Sudu, „predmet“ zahtjeva za tumačenje leži u pitanju nacionalne zakonske odredbe koja ga je „pokrenula“, dok je ,uzrok“ postupka u odredbi članka 267. stavak 3. Ugovora o funkcioniranju Europske unije, koji može utjecati na činjenicu da je pitanje koje se postavlja materijalno istovjetno pitanju o kojem je već odlučeno u sličnom slučaju.$^{55}$ Pristup Suda je mudar. Komisiji, koja je na temelju apsolutnog autoriteta res judicata, smatrala da bi postavljena pitanja trebala biti odbijena jer je pitanje već riješeno u prethodnoj presudi, Sud odgovara da je domaći sudac uvijek slobodan procijeniti potrebu takvog upućivanja. Ali, istodobno, zastupnicima ideje relativnog autoriteta, on odgovara da njegova misija nije riješiti spor, već da „u konkretnom slučaju spora koji je u tijeku pred nacionalnim sudovima, izvede apstraktno tumačenje slova i duha ugovora“". ${ }^{56}$

54 Sud Europske unije, 23. ožujka 1963., Da Costa en Schaake, spojeni predmeti 28, 29, 30/62.

55 Ibid.

56 Sud Europske unije, 23. ožujka 1963., Da Costa en Schaake, spojeni predmeti 28, 29, 30/62. 


\subsection{Temelji autoriteta tumačene stvari u interpretativnim prosudbama}

Autoritet tumačene stvari, dodijeljen sudskoj praksi, razlikuje se od autoriteta tumačene norme. To se tumači s obzirom na interpretativnu funkciju koja je povjerena Sudu. Kao jedini kvalificirani tumač volje autora ugovora, njegova je misija rasvijetliti odredbe zakona sadržane u primarnim izvorima, kako bi se laicima, osobito državama članicama, otkrila stvarna volja, do tada virtualna, autora ugovora. Dakle, on razotkriva pravnu normu kroz evolutivno čitanje i teleološko tumačenje odredbi konstitutivnog ugovora. Poput dinamičnih institucija, Sud je kreator normi koje proširuju primarno pravo. On ne stvara neko drugo pravo čija bi egzistencija bila paralelna i drukčija od prvog, već razvija postojeće pravo, obogaćuje ga i produbljuje. U tom smislu tumačenje postaje sastavni dio tumačene pravne norme.

R. Chapus je naglasio: „tumačenje se miješa s interpretiranom normom: ono predstavlja sam sadržaj akta o kojem je riječ. Stoga se ono nameće kao jednakovrijedno

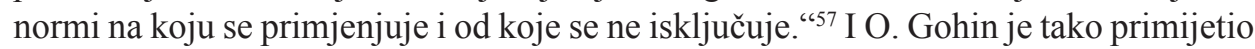
da „Sud određuje pravna pravila umjesto država članica i umjesto vlasti zajednice, autora ugovora i akata za njegovo provođenje. Na taj način, on kreira pravo koje se inkorporira u tumačenu normu, te ima jednaku vrijednost. Doseg njegove presude ne procjenjuje se, dakle u terminima res iuducata, nego proizlazi iz stvarne legislativne vrijednosti ili regulatorne vrijednosti koja se pridaje sukladno prirodi interpretiranog akta. On stoga ima erga omnes efekt i manifestira se u apsolutnom smislu kao u tumačenom tekstu““. ${ }^{88} \mathrm{~A}$ D. Chabanol dodaje da se tumačenje ,inkorporira u pravnu normu koju interpretira na način da nestaje zajedno s njom“. Interpretativna presuda jednaka je novoj formulaciji zakona. ${ }^{59}$

Autoritet sudskog tumačenja utvrđuje se presudom, koja razvija inicijalno pravilo. Autoritet se prenosi na tumačenu normu, dakle radi se o ,autoritetu tumačene stvari“. Zbog toga je legitimno pozvati se na pravila sudske prakse, na isti način na koji govorimo o ustavnim ili zakonodavnim pravilima, ne radi samog postupanja suda, nego zbog asimiliranja inkorporacijom tumačenja i tumačene pravne norme. Sud kao kvalificirani tumač odredbi prava Zajednice, ne zamjenjuje primarnu nadležnost autora.

Dakle, priznavanjem njegovog autoriteta ne riskira se „zaključavanje“ Suda Europske unije u vlastitom tumačenju, na način da on više ne bude u stanju razviti ili ispraviti svoju sudsku praksu. Čini se da je upućivanje na autoritet tumačene stvari omogućilo prevladavanje ove poteškoće. Da bi to učinio, potrebno je prihvatiti razliku koju je Sud uveo između apsolutnog autoriteta i promjenjivosti interpretativne odluke. Želeći spriječiti statističke vrijednosti interpretacijskih odluka, prihvatio je mogućnost da se nacionalni sudovi ponovno obraćaju Sudu s pitanjima u odnosu na tumačenja koja su već donesena, ali čije značenje i opseg otvaraju nova pitanja. Ova mogućnost nije kršenje, niti odstupanje od načela apsolutnog autoriteta tumačenja. Ona proizlazi iz suštinske razlike između autoriteta i nepromjenjivosti. Iz sudske prakse Zajednice

57 Više o svemu vidi: Chapus, R., Droit du contentieux administratif, Pariz, Montchrestien, 12. izd., 2008, str.121-196.

58 Više o tome: Gohin, O., Contentieux administratif, 2. izd., Pariz, Litec, 1999, str. 81-87.

59 Vidi: Chabanol, D., Le juge administratif, Pariz, LGDJ, 1993, str. 79-98. 
proizlazi sljedeće načelo: svako tumačenje Zajednice po svojoj prirodi ima apsolutni autoritet $\mathrm{u}$ odnosu na nacionalne vlasti i institucije Zajednice, uzimajući u obzir, međutim, razloge svojstvene logici i dinamici sustava Zajednice, koje mogu izazvati njegovu djelomičnu ili potpunu izmjenu te posljedičnu zamjenu novim tumačenjem istog karaktera. Tumačeni tekst dakle može biti predmetom novih tumačenja, a da to nije kršenje autoriteta res judicata. ${ }^{60}$

Tumačenja Suda manifestacija su izvršenja prerogativa javne vlasti. Za države članice i institucije Zajednice, ona imaju apsolutni autoritet tumačene stvari, koji ih obvezuje da se pridržavaju pravnih normi proizašlih iz sudske prakse, a koje su uključene u protumačenu odredbu. Obvezujući učinak tumačene norme tada određuje obvezujuću snagu sudske interpretacije. Ona time dobiva normativnu neposrednost, postaje trenutno i istodobno primjenjiva u svim državama članicama te protiv djelovanja tijela javne vlasti, kao i tijela privatnog prava.

Također, na nju se primjenjuje načelo primata prava Zajednice, čije implikacije objašnjavaju obvezujuću snagu interpretativnih odluka koje je donio Sud Europske unije. U konačnici, jedino ograničenje s kojim se Sud suočava jest ne prekoračiti „prag tolerancije koji se nameće njegovom interpretativnom djelovanju, kako bi se zadržao konsenzus država članica u odnosu na sudske odluke" ${ }^{61}$ Problem se postavlja u različitim terminima s obzirom na opća načela. Teško je reći da su oni uključeni u tumačenu normu, jer se najčešće proizvode bez ikakve tekstualne osnove. S druge strane, ako mogu preuzeti inspiraciju iz državnih ili konvencionalnih ustavnih načela, neće moći preuzeti nikakvu vlast u pravnom poretku Zajednice. Opća načela zakona nisu izvan pozitivnoga pravnog poretka, oni su dio nje, ali nemaju vlastitu egzistenciju: „to je sudac koji im daje snagu i život" ${ }^{62}$ Iz te točke gledišta, s formalnog i organskog stajališta, iz sudske prakse oni imaju svoje ovlasti. Njihova jurisprudencijska priroda daje im autoritet koji je dostupan pravosuđu Zajednice u ostvarivanju ovlasti koje su mu dodijeljene. Sud razmatra opća načela prava Zajednice kao dio pravnog sustava Zajednice za koji osigurava usklađenost. U stvarnosti, to je "super-zakonitost“ ako se nameće institucijama u razvoju i primjeni sekundarnog zakonodavstva. $\mathrm{Ne}$ primjenjuju se na radnje iz djelokruga njihovih rezerviranih ovlasti ${ }^{63}$ ili koje nisu u nadležnosti prava Zajednice, ${ }^{64}$ već su nametnute mjerama poduzetim na temelju prava Zajednice. ${ }^{65}$

Iz ovih razmatranja slijedi da su interpretativna sudska praksa, kao i opća načela prava Zajednice, pravi zakonski činovi, smještene na istoj razini kao i izvorni tekstovi. Imaju obvezujuću vrijednost, superiornu od sekundarnog zakonodavstva, što obvezuje institucije Zajednice i države članice. U tom su izrazu ovlasti Suda Europske unije. Ovo

60 Ibid., str. 79-98.

61 Simon, D., L'interprétation judiciaire des traités d'organisations internationales, Pariz, Politique étrangère, 1982, str. 773.

62 Jeanneau, B., La nature des principes généraux du droit en droit français, Pariz, Travaux de recherches de l'Institut de droit comparé de l'Université de Paris, T. XXIII, 1962, str. 203.

63 Sud Europske unije, 11. srpnja 1985., Cinéthèque, spojeni predmeti 28, 29, 30/62.

64 Ibid.

65 Sud Europske unije, 26. travnja 1988., Hauptzollamt Hamburg Jonas c/ Krüchen, spojeni predmeti 316/86. 
je tijelo uvjet ispunjavanja misije nadležnosti; dopušta Sudu, instrumentu europskog jedinstva, da uspostavi svoju nadležnost. Konačno, valja istaknuti da je autoritet Suda naglašen činjenicom da ga ne nosi nikakva institucionalna ili funkcionalna protuteža, kao što je većina nacionalnih vrhovnih sudova.

\section{ZAKLJUČAK}

Tumačenje pravnih pravila, ako je primijenimo na upravno sudstvo, može se mjeriti samo kao „process” koji se tiče izrade sudskih odluka: kvalitetno sudstvo trebalo bi biti u stanju kvalitetno tumačiti pravne propise. Tekstualne definicije ponekad nisu cjelovite, sažete ili jednostavno ne postoje, pa postaje nužno u sudskom postupanju namijenjenom upravnom aktu istraživati dominantna mjerila za definiciju, a znamo da ove dvije istraživačke metode o sastavnicama pojma upravnog akta, tekstualni temelj ili pristup kroz spor, svakako nemaju svrhu isključivanja, već naprotiv, nadopunjavanja.

Danas je sudska praksa, kao pravna i društvena potreba i nužnost, općenito prihvaćena. Sudska praksa nije samo pravni, već i društveni fenomen, utoliko što je ona način rješavanja sukoba u društvu. Tako svi društveni odnosi, koji zahtijevaju intervenciju zakonodavca, mogu pružiti sudcu priliku da postavi pravila upravnosudske prakse. Poslanje sudca, kako god ono bilo osjetljivo, neophodno je. Nikad savršen, zakon je, u najboljem ruku, najbolji u određenom trenutku, ali samo u tom trenutku. Na sudcu je, dakle, da kaže ne samo što je zakonito, a što nije, nego i da kaže što je istinito, što je dobro i što je pravedno. Upravo na taj način, upravni sudci pridonose koherentnosti pravne države.

Isto tako, treba naglasiti kako su i metode pravnog tumačenja evoluirale. Naime, osim dogmatskog tumačenja pozitivno pravnih propisa, potrebno je sve više usvajati i teleološko tumačenje pravnih propisa (ciljeve pravnih propisa). Ciljno tumačenje pravnih pravila proces je koji upravno sudstvo, ma koliko ono bilo neovisno, više ne može zaobići.

Prema načelu djelotvornosti, nacionalna pravila postupka ne smiju učiniti ostvarivanje prava zajamčenih propisima Europske unije praktično nemogućim ili pretjerano teškim. S obzirom na važnost načela djelotvornosti, „pravo na sudca“, pravo pristupa upravnim sudovima bitan je element, koji mora biti konkretan i djelotvoran, a ne samo teorijski. U pravu Europske unije, načelo djelotvornosti zahtijeva da nacionalna postupovna pravila u praksi ne čine nemogućim ili iznimno teškim ostvarivanje prava koja pojedincima daje pravni poredak Unije ${ }^{66}$ Nacionalni upravni sudovi su tako obvezatni tumačiti i primjenjivati nacionalna postupovna pravila na način koji omogućuje strankama u postupku da imaju djelotvorno pravno sredstvo kako bi se omogućilo osiguranje prava koja proizlaze iz europskih pravnih propisa. ${ }^{67}$

66 Sud Europske unije, 10. travnja 2003., Steffensen, predmet C-276/01; Sud Europske unije, 3. rujna 2009., Fallimento Olimpiclub, predmet C-208.

67 Sud Europske unije, 23. travnja 1986., Zeleni protiv Europskog parlamenta, predmet 294/83; Sud Europske unije, 27. veljače 2007., Gestoras Pro Amnistia protiv Savjeta, predmet C-354/04. 
Sve je navedeno razlog zbog kojeg u Republici Hrvatskoj naglasak treba biti stavljen na usvajanju europskih pravnih propisa i sudske prakse, razvoju metode primjene i tumačenju pozitivnog prava te praćenju evolucije sudske funkcije slične onoj koju su države članice Europske unije već doživjele. Svemu ovomu treba pridodati minimalno poznavanje poredbenoga prava i velikih pravnih sustava glavnih država članica Europske unije.

Danas u Hrvatskoj, rješavanje u upravnom sporu znači primjenjivanje nacionalnih pravila, ali i europskih pravnih normi u sve većoj mjeri.

Budući da se pravilo odražava u presudi, presuda treba što je moguće preciznije prenijeti stvarni smisao zakona i misao sudca koji taj zakon primjenjuje, a ukupnost presuda treba moći činiti skladnu cjelinu. Obrazloženje daje legitimitet odluci i ujedno je objašnjava.

Upravni sudci imaju zadaću ne samo primjenjivati zakon, već ga i tumačiti. Eventualne nejasnoće u primjeni, upravni sudovi moraju riješiti primjenom nacionalnih, europskih, pa čak i međunarodnih propisa te u svjetlu posve novih načela. S jedne strane, tu su norme koje potječu iz prava Europske unije iz kojih proizlazi obveza osiguranja učinkovite zadaće subjektivnih prava. S druge strane, tu su norme koje potječu iz Europske konvencije za zaštitu ljudskih prava i temeljnih sloboda, osobito zahtjeva u vezi s pravom na djelotvorni postupak i pravom na pošteno suđenje kako ih tumači Sud u Strasbourgu. Te promjene nalažu, među ostalima, upravnim sudcima da ulažu pojačane napore kako bi uskladili svoje odluke, ustalili i pojasnili pravno tumačenje koje proizlazi iz njihovih odluka. Način na koji bi upravni sudac danas trebao osmišljavati svoje ovlasti pune jurisdikcije mora biti rezultat suvremenog razmišljanja o njegovoj službi, o njegovoj dužnosti. Sudac ima veliku slobodu izbora u ovlastima koje provodi u granicama svoje nadležnosti i samostalno određuje načine na koje će vršiti svoju kontrolu.

Danas, općenito promatrano, najvažnija pravna i politička karakteristika upravnog sudovanja je zaštita građana od nezakonitoga djelovanja javnopravnih tijela.

Danas više ne postoji nikakva sumnja u postojanje interakcije između nacionalnih i europskih sudova. One su očite, brojne i zbog višestrukih razloga neophodne. Svaki je sud brzo razumijevao korisnost interakcije sa svrhom koja se odnosila na obogaćivanje svoje sudske prakse. Nacionalna dimenzija je očigledna. Kada govorimo o dimenziji zajednice i europskoj dimenziji, jasno nam je da je i Sud Europske unije, na kompleksan način, ali ipak, među ovim sudionicima.

\section{LITERATURA}

\section{Knjige i članci}

1. Aviani, Damir, Đerđa, Dario, Uniformno tumačenje i primjena prava te jedinstvenost sudske prakse u upravnom sudovanju, Split, ZPFS, vol. 49, 2/2012, str. 369-394.

2. Boré, Louis, La motivation des décisions de justice et la Convention européenne des droits de l'homme, Pariz, JCP, 2002.

3. Britvić Vetma, Bosiljka, Kvaliteta odluka upravnih sudova, Split, ZPFS, vol. 51, 2/2014, str. 393-414.

4. Britvić Vetma, Bosiljka, Suradnja između nacionalnih upravnih sudova, Suda Europske 
unije i Europskog suda za zaštitu ljudskih prava, Rijeka, ZPFR, vol. 35, 1/2014, str. 219244.

5. Britvić Vetma, Bosiljka, Ljubanović, Boris, Suradnja između nacionalnih upravnih sudova, Suda Europske unije i Europskog suda za zaštitu ljudskih prava u izvršavanju upravnosudskih odluka nakon Lisabonskog ugovora, Split, ZPFS, vol. 52, 2/2015, str. 431-447.

6. Chabanol, Daniel, Le juge administratif, Pariz, LGDJ,1993.

7. Chapus, Rene, Droit du contentieux administratif, 12. izdanje, Pariz, Montchrestien, 2008.

8. Đerđa, Dario, Načelo razmjernosti u donošenju upravnih odluka, Rijeka, ZPFR, vol. 37, 1/2016, str. 175-200.

9. Đerđa, Dario, Učinak europskih pravnih pravila na pravno normiranje upravnog postupka u Hrvatskoj, Split, ZPFS, vol. 50, 2/2013, str. 393-427.

10. Đerđa, Dario, Šikić, Marko, Komentar Zakona o upravnim sporovima, Zagreb, Novi informator, 2012.

11. Gaudemet, Yves, Droit administratif, Pariz, L.G.D.J., 2005.

12. Ghirardi, A. Olsen, Le raisonnement judiciaire, Pariz, Ed. Bière, Bibliothèque de philosophie comparée, 2000.

13. Gohin, Olivier, Contentieux administratif, 2. izd.,Pariz, Litec, 1999.

14. Guinchard, Stéphanie, La théorie de l'apparence en droit administratif: vertus et risques de l'importation d'une tradition de Common law, Pariz, RD publ., 2005.

15. Harašić, Žaklina, Autoritet i sud, Split, ZPFS, vol. 52, 2/2015, str. 407-429.

16. Jeanneau, Benoit, La nature des principes généraux du droit en droit français, Pariz, Travaux de recherches de l'Institut de droit comparé de l'Université de Paris, T. XXIII, 1962.

17. Jeuland, Emmanuel, La motivation, u Dictionnaire de la Justice, Pariz, Loïc Cadiet, PUF, 2004.

18. Mertens de Wilmars, Joss, La jurisprudence de la Cour de justice comme instrument de l'intégration communautaire, Bruxelles, C.D.E., 1976., n¹2.

19. Simon, Denys, L'interprétation judiciaire des traités d'organisations internationales, Pariz, Politique étrangère, 1982.

20. Spencer, R. John, Quelques observations préliminaires, in Juges et jugements: l'Europe plurielle, l'élaboration de la décision de justice en droit comparé, Pariz, Société de législation comparée, 1998.

21. Staničić, Frane, Britvić Vetma, Bosiljka, Horvat, Božidar, Komentar Zakona o upravnim sporovima, Zagreb, Narodne novine, 2017.

22. Šikić, Marko, Ofak, Lana, Nova načela upravnog postupka (s posebnim naglaskom na razmjernost, legitimna očekivanja i stečena prava), Rijeka, ZPFR, vol. 32, 1/2011, str. 127-153.

23. Teitgen, Pierre-Henri, Cours de droit institutionnel communautaire. Structure et fonctionnement des Communautés européennes, Licence $4^{\mathrm{e}}$ année, Pariz, Les cours de droit, 1976-1977.

24. Trabucchi, Alberto, L'effet erga omnes des décisions préjudicielles, Pariz, R.T.D.E., 1974.

25. Waline, Marcel, Le pouvoir normatif de la jurisprudence, La technique et les principes du droit public, Etudes en l'honneur de G. Scelle, Pariz, L.G.D.J., 1950. 


\section{Bosiljka Britvić Vetma*}

Summary

\section{THE ROLE OF ADMINISTRATIVE COURTS AND THE EUROPEAN UNION COURT IN THE CREATION OF LEGAL REGULATIONS AND ADMINISTRATIVE COURT PRACTICE}

This paper primarily deals with the role of administrative courts in the creation of legal regulations. How legal regulations are interpreted is emphasised as is how the quality of interpretation also defines the quality of court practice. The author emphasises that it is not always an easy task. How court practice is not a legal but also a social phenomenon is mentioned. So too are all relations that require legislative intervention. They can offer the judge the opportunity to develop rules of court practice. Even though court practice can never replace the legal rule, it is certainly a logical continuation or extension of legal rules and even an indispensable addition. Therefore, it is court practice's subject of interest which is as varied as the subject of legal rules' interest. That is why the contribution of administrative court practice and its role is equally as important in the life of the individual as it is in public life. Given that the rule is maintained in the judgement, the judgement should as precisely as possible express the real meaning of the law and the thought of the judge who applies that law. The totality of the judgement should comprise a harmonised whole. The explanation gives the decision legitimacy and at the same time explains it. The author also analyses the limits of the application of the judgement of the European Union Court. This includes the interpretative role as well as which obligations the European Union Court judgement sets before the member state and its citizens. At the same time, it points out how national administrative judges should behave towards them.

Keywords: purposive interpretation; conditions for administrative court practice formation; meaning of administrative court practice; role of the European Union Court in the creation of administrative court practice.

* Bosiljka Britvić Vetma, Ph.D., Associate Professor, University of Split, Faculty of Law; bosiljka.britvic@pravst.hr. 
Zussamenfassung

\title{
DIE ROLLE DER VERWALTUNGSGERICHTE UND DES GERICHTSHOFS DER EUROPÄISCHEN UNION IN DER KREIERUNG VON RECHTSVORSCHRIFTEN UND VERWALTUNGSRECHTSPRECHUNG
}

\begin{abstract}
Dieser Beitrag bespricht in erster Linie die Rolle der Verwaltungsgerichte in der Kreierung von Rechtsvorschriften. Es wird betont, dass die Auslegung von Gesetzesvorschriften sowie auch die Qualität dieser Auslegung auch die Qualität der Rechtsprechung selbst definiert. Ebenfalls wird betont, dass das nicht immer eine leichte Aufgabe ist. Im Beitrag wird behauptet, dass die Rechtsprechung nicht nur ein Gerichts- sondern auch ein Gesellschaftsphänomen ist. Deshalb bieten alle gesellschaftliche Verhältnisse, welche den Eingriff des Gesetzgebers fordern, dem Richter die Angelegenheit, die Regeln der Rechtsprechung durchzuarbeiten. Obwohl die Rechtsprechung die Rechtsregel nie ersetzen kann, ist sie auf jeden Fall die logische Fortsetzung der Rechtsregeln, oder sogar eine notwendige Ergänzung. Demnach ist der Gegenstand des Interesses der Rechtsprechung so verschiedenartig wie auch jener der Rechtsregeln. Der Beitrag und dir Rolle der Verwaltungsrechtsprechung sind deshalb ebenso wichtig sowohl für das Leben des Einzelnen als auch für das öffentliche Leben. Da sich die Regel in der Gerichtsentscheidung wiederspiegelt, sollte die Entscheidung möglichst präziser den eigentlichen Sinn des Gesetzes und den Gedanken des Richters, der dieses Gesetz anwendet, übermitteln. Die Gesamtheit der Entscheidungen sollte eine harmonische Ganzheit bilden können. Die Entscheidungsgründe geben der Entscheidung eine Legitimität und gleichzeitig erklären sie sie. Das Ausmaß der Anwendung der Entscheidungen des Gerichtshofs der Europäischen Union, die auslegende Rolle des Gerichtshofs der Europäischen Union sowie auch die von Entscheidungen des Gerichtshofs der Europäischen Union auferlegten Verpflichtungen für den Mitgliedsstaat und seine Bürger werden analysiert. Ebenfalls weist dieser Beitrag daraufhin, wie sich die Richter der Verwaltungsgerichte in nationalen Mitgliedsstaaten diesen Entscheidungen gegenüber verhalten sollten.
\end{abstract}

Schlüsselwörter:teleologische Auslegung; Voraussetzungen für die Kreierung der Verwaltungsrechtsprechung; Bedeutung der Verwaltungsrechtsprechung; Rolle der europäischen Gerichte in der Kreierung der Verwaltungsrechtsprechung. 
Riassunto

\section{IL RUOLO DEI TRIBUNALI AMMINISTRATIVI E DELLA CORTE DI GIUSTIZIA DELL'UNIONE EUROPEA NELLA CREAZIONE DELLE NORME GIURIDICHE E DELLA GIURISPRUDENZA AMMINISTRATIVA}

Nel presente lavoro in primo luogo si valuta il ruolo dei tribunali amministrativi nella creazione di precetti giuridici. Si rileva come l'interpretazione delle disposizioni di legge, come pure la qualità della stessa determini anche la qualità della giurisprudenza. L'autore inoltre evidenzia la difficoltà di tale compito. Osserva infatti come la giurisprudenza rappresenti non soltanto un fenomeno giuridico, ma anche sociale. Così tutti i rapporti sociali, che richiedono l'intervento del legislatore possono dare al giudice l'occasione di arricchire la giurisprudenza. Benché la giurisprudenza non possa mai sostituire la regola giuridica, essa comunque rappresenta la continuazione logica delle regole giuridiche, o meglio ne costituisce la necessaria prosecuzione. Pertanto l'oggetto di interesse della giurisprudenza è variegato tanto quanto il contenuto delle norme giuridiche. Pertanto 1'apporto alla giurisprudenza amministrativa ed il suo ruolo sono al pari importanti come nella vita del singolo, così anche nella vita pubblica. Posto che la regola trova espressione nella sentenza, questa deve riportare quanto più precisamente possibile il senso della norma ed il pensiero del giudice che applica tale norma, mentre la sentenza deve risultare in un'unità armonica. La motivazione offre legittimità alla decisione e nel contempo la spiega. L'autore inoltre nel testo disamina fino a che confini giunge l'applicazione della giurisprudenza della Corte di Giustizia dell'UE; valuta il ruolo interpretativo di tale Corte e disamina quali obblighi le sentenze della Corte pongono dinnanzi allo Stato membro ed ai suoi cittadini. Al contempo illustra in quale modo i giudici amministrativi nazionali debbano porsi dinnanzi a dette decisioni.

Parole chiave: interpretazione mirata; condizioni di formazione della giurisprudenza amministrativa; significato della giurisprudenza amministrativa; ruolo delle corti europee nella creazione della giurisprudenza amministrativa. 
